\title{
EAl Endorsed Transactions

\section{Waste Management in Smart Cities: A Survey on Public Perception and the Implications for Service Level Agreements}

\author{
A. McCurdy ${ }^{1}$, C. Peoples ${ }^{1, *}$, A. Moore ${ }^{1}$ and M. Zoualfaghari ${ }^{2}$ \\ ${ }^{1}$ Ulster University, UK. \\ ${ }^{2}$ BT Technology, BT Group, UK.
}

\begin{abstract}

INTRODUCTION: Waste management in cities has not advanced at the same rate as technology in general. Furthermore,
there is little evidence that citizens are satisfied with services in smart cities.
OBJECTIVES: The objective of this paper is therefore to capture citizen perspectives in relation to smart city services and,
specifically, that of waste management.
METHODS: An online survey was disseminated using Google Forms to twenty-five homeowners within the Tourism
Ireland office in Coleraine, Northern Ireland. The objective was to gather the typical citizen perspective of smart cities,
their views on the meaning of 'smart waste management', and any features which they would like to experience with
regard to their waste collection process and/or schedule in a future smart city.
RESULTS: It was found that a common perception of a smart city exists, it being one concerned with efficiency and
recycling; fewer citizens are, however, familiar with the term 'smart waste management'. Homeowners generally
acknowledge that improvements to their current bin collection schedule are necessary.
CONCLUSION: The paper concludes with a discussion of the ways in which citizens believe that a bin collection schedule
which they are in control of would be an improvement on a council-defined one. We correlate this with extensions
necessary to service provisioning processes, and Service Level Agreements (SLAs), to support future smart city services.
\end{abstract}

Keywords: smart city, waste management, citizen perspectives, survey, Service Level Agreements (SLAs).

Received on 06 February 2021, accepted on 24 May 2021, published on 27 May 2021

Copyright (C) 2021 A. McCurdy et al., licensed to EAI. This is an open access article distributed under the terms of the Creative Commons Attribution license, which permits unlimited use, distribution and reproduction in any medium so long as the original work is properly cited.

doi: 10.4108/eai.27-5-2021.170007

*Corresponding author. Email: c.peoples@ulster.ac.uk

\section{Introduction}

Published in 2018, it is noted in [1] that, “... the literature of IoT still lacks studies on the behavioural aspect that explain the customers' perception towards IoT adoption and focuses more on technological aspect". This is significant, recognising that we, as developers, do not generally know if citizen needs are being met in the solutions provided. This is compounded by the fact that, despite smart cities being put in place for citizen convenience, it is recognised that, "smart city initiatives are launched without the citizens' evaluation of the improvements made to their city" [2]. This is also important, given that, "the most valuable resource of a city is its residents" [3]. The Eden Strategy Institute acknowledges this and, when ranking the top 50 smart cities worldwide, they evaluate using factors which include, "A sincere, people-first design of the future city" [4]. "When people live in close proximity, everyone and everything must work together" [5]. It is therefore critical that the systems put in place respond to the needs of a city's citizens.

Waste management in cities has not advanced at the same rate that technology has in general, and it continues to rely on a more traditional approach of collecting bins on a set schedule and route. Given recent advancements in the use of technologies to make decisions in a more 
dynamic and responsive manner, there is clearly an opportunity to optimise this process. Furthermore, citizens are diverse in their characteristics, and therefore in their use of city services - by responding to this in a more personalised way there is a further benefit of improving homeowner satisfaction. It subsequently became our aim to gain an appreciation of citizen perspectives on the concept of smart waste management, as one area of focus in smart cities. A survey with homeowners was performed, and the results capture views on the concept of smart cities in general, before focusing on smart waste management and limitations with regard to current waste collection processes. We also capture ideas on ways which citizens would like services to be improved in the future. It is our objective that the results collected through the survey will support us in our objective of understanding current perceptions so that smart city solutions may be more suitably targeted towards them.

The research presented in this paper is explored within the context of waste management in Northern Ireland. This involves a black bin for general waste and a blue bin for recyclable waste. Each bin is emptied on a fixed schedule, with the black bin scheduled one week, and the blue bin the next. There are opportunities to optimise the efficiencies of this process, in addition to improving the general satisfaction of homeowners. With a bin collection schedule on a fortnightly basis, there is the possibility of bins needing to be emptied earlier. Homeowners are not however, in a position to request such a service, and if they need a more frequent service, they must take their waste to a remote collection point. Furthermore, homeowners generally have very distinct characteristics, from the number of people living within a home to the average amount of waste generated. Therefore, it is not logical to expect that every home is subject to an identical waste collection schedule. In the past, there have been few opportunities to personalise the waste collection process, however, the advent of smartness through modern technologies means this is now possible. It is pertinent therefore to discover not only how the technologies may be used, but also the ways in which citizens want them to be used. It is therefore in response to these objectives that the research presented in this paper is carried out.

The remainder of the paper is organised as follows: In Section 2, a literature review is presented on the variety of definitions of smart cities, with a view to help us to determine the extent to which our survey respondents have an accurate understanding of the concept. Section 2 also contains a review the concept of smart waste management, together with a review of the way that a selection of smart waste management schemes, proposed in the literature and also in state-of-the-art deployments, operate. The research methodology supporting our survey is presented in Section 3, and is followed in Section 4 with a discussion of our survey results and summary findings. Smart waste management challenges are discussed in Section 5 and the ways in which service provisioning processes need to expand are considered in
Section 6. The paper concludes and considers future work in Section 7.

\section{Literature Review}

A smart city is one designed to operate in a manner which is optimised to the needs and behaviours of the citizens existing within it. Optimisation in this context refers to systems which fulfil citizen needs and which make their lives more convenient; this includes pre-empting future needs. In line with a definition from the UK Department for Business, Innovation and Skills, this accommodates their definition of a smart city, as one which uses technologies to make a city "more liveable" [1]. It also takes into account a definition in [6], in which it is recognised that, "The anthropomorphism (attribution of human characteristics to the city) of the city is based on it being able to sense and respond to its challenges smartly". This clearly considers a smart city as being able to adapt and continue to meet the needs of the citizens within the dynamic environment.

Boyd Cohen classifies a smart city in six ways: Smart People, Smart Economy, Smart Environment, Smart Government, Smart Living, and Smart Mobility [7]. Cisco presents a more explicit, and perhaps less organised, classification, considering a smart city as one which incorporates technologies to influence Air Quality, Communication Architecture, Environment, Lighting, Parking, Public WiFi, Safety and Security, Transportation, Urban Mobility, Waste Management, and Water Management [8]. The ITU-T Study Group 20 focuses their work on the Internet of Things and Smart Cities and Communities [9]. This group is less explicit in categorising the core aspects of the IoT and smart city, and instead describe it as supporting: “... increasing urbanization trends, smarter and more sustainable means of managing urban complexities, reducing urban expenditure, increasing energy efficiency and improving the quality of life for urban residents ..." [10].

Differences in these definitions from industrial players is important - the fact that a single distinct definition does not exist on the concept of a smart city means that it is open to variation in its interpretation. This is significant, particularly at this point in time, when the network landscape is becoming more populated and developed, and at a time when efforts are being directed into the difficult challenge of standardising this challenging environment: work is currently underway on this by the European Telecommunications Standards Institute (ETSI) [11], for example, and the European Commission [12], as another.

Smart waste management, as one area where technology contributions can improve convenience in smart cities, can refer to the concept of dynamic waste collection, in the sense that the bin collection mechanism operates on the amount of waste as opposed to more strictly following a weekly schedule [10]. This scheme is also followed in [13], with the authors additionally 
proposing that waste stakeholders are informed of the type of waste which will be arriving at the plant in advance, such that they can plan for more effective management through recycling. While important and relevant, there is little evidence that this responds to citizen needs, or that citizen requirements have been taken into account. As a further example, IBM consider in [14] a component of smart waste management as informing others on the real-time waste situation across a city or country, and the impact of this financially and environmentally. Again, it might be argued that this does not respond to the needs of citizens. In contrast, "Solarpowered, IoT-connected bins installed in UK borough" were reported in July 2018 by Government Europa [15]. The bins were deployed in pairs, with one for general waste and one for recycling. In addition to being solarpowered, with powering for the objective of communicating sensor data with a centralised data repository, the state-of-the-art bins also have a compaction system to increase bin capacity. Waste levels are reported by the bin to the council for a collection strategy influenced by fill level. It is more likely that such an approach will respond to citizen needs, by avoiding situations where bins are full through reaction to customer activity.

In [16], smart waste management is achieved using a route calculated on a daily basis for waste collectors, which has been optimised based on the bin levels recorded using sensors. The scheme is supplemented with ability to predict bin level using historical evidence. This information is combined with information on traffic congestion in an area to avoid situations of over-flowing bins and to achieve this in an effective and efficient manner. In an attempt to avoid an inefficient and nonoptimised solution, the authors explore effectiveness of the waste collector visiting only those areas where $70 \%$ of the waste bins have a level above a threshold. This avoids potential situations where, for example, only one bin in the region is full and the waste collector is sent to deal with to an individual bin.

The smart cheap city is considered from the perspective of waste management in [16]. The efficiency of implementation here is in relation to the hardware components used, in terms of Passive Infrared Sensors, which are a cheap way to detect motion and the voltage of the output, which means that the sensor can be connected directly with the board without the use of logical level converters. A persistent clock is also used to ease maintenance. In terms of the waste collection algorithm, the authors propose calculating the shortest path between the bins, and additionally taking into account the time to service each location. Bins are categorised according to the level to which each is full. $50 \%$ capacity indicates that it can be collected in the next route planning, and is marked as yellow. 90\% capacity indicates that it should be collected, and is marked as red. A collection will be scheduled when any bins are marked red, and any yellow bins will additionally be collected at this time.
More recently, Mahmood and Zubairi (2019) describe a smart approach to waste management applied in Islamabad, Pakistan [17]. The system was responsible for influencing the path taken by waste collectors when considering time and distance constraints. Technology supporting the end-to-end operation include range sensors, communication modules, an online dashboard, and a mobile navigation for use on collection trucks. The algorithm uses the bin waste level, which is communicated at periodic intervals to the central server. The route is calculated with a focus of minimising the number of trucks needed, and is based on where the load will be collected, where it should be transported to, and the need for any items to be off-loaded at different locations. The aim is to service a customer site once by a single vehicle, which is a challenge taking into account the variety of recyclables which might be collected. The approach positively demonstrates reduced cost and time associated with waste collection. A similar approach is described in [18], which supports bin monitoring. The proposed scheme uses RFID technology, sensors, and cloud technology. The bin weight is used to influence the decision-making process, and is provided by the RFID tag along with a timestamp, and detail on the bin location and bin owner.

Collecting information to influence the route collection strategy is one aspect of smart waste management. As another example, the authors in [19] identify that waste separation complicates collection processes, given that there is a need for different receptacles to hold each type of waste and that different collection trucks are needed for each type. In response to this inefficiency, they discuss the use of split deliveries for collections and for each waste stream to optimise operation.

It is interesting, however, that, despite the variety of approaches in the literature which suggest similar approaches to managing waste collection, that there are few deployments in reality. Developments in this area is mainly from the perspective of research, as opposed to those deploying and investing in this area. It is therefore relevant to examine the work of industrial players in this field: In terms of state-of-the-art in smart waste management schemes, the IBM Intelligent Waste Management Platform [14] collects information with a view to reducing waste management costs. Waste management data collected includes the route frequency, the bin weight, and demographic information, such as income, age and building type. Additionally, non-waste data can supplement this information, with relevant information including precipitation and population density. This can be processed to understand waste management finances, and an outreach portal communicates to customers on their waste management status.

enevo [20] aims to overcome and avoid situations of poor waste management. This involves hourly waste management measurements. Solutions are delivered by enevo to businesses, which involve training staff, deploying food waste programs, and consideration of 
alternative collection approaches for specialised items. Approaches are considered for their applicability in cities, restaurants, retail, commercial real estate, and multifamily residences.

Big Belly Smart City Solutions produces high-tech solar-powered bins with built-in compactors to accommodate five times the capacity of an equivalent bin. These bins are aimed to be used in public locations within a city as they can come equipped with built-in WiFi access points and a range of sensors to measure pedestrian traffic walking past the bin, noise and pollution levels. The bins also have sensors to measure the fill level which is sent to their cloud-connected software CLEAN Collection, Logistics, Efficiency And Notification. When it reaches capacity after compacting applied, it triggers a notification to the local council, informing that it is now ready for collection. The CLEAN software provides a visual representation of all the bins connected with their current fill level, with an emphasis on insights, analytics, and reporting tools. Recycling waste streams, public space guides and route planning stakeholders not involved in the day-to-day operations instantly are able to see improvements of collections.

Cisco Kinetic for Cities Waste Management [21] involves real-time visualisations of waste bins for more informed decisions, and alerts about bins, in terms of fires or bin movement, to bring about citizen awareness in waste management issues. Another feature of this scheme is route optimisation, with the goal of lower carbon emissions as a result of a reduced number of wastecollection vehicles needed. In an attempt to integrate the standalone solutions which have been deployed to date, Cisco Kenetic supports multivendor integration. This feature allows inputs into the waste management solution which are vendor agnostic.

Smart waste management is a relatively popular research topic, and deployment of show-case technologies can be seen. However, these are largely disjoint solutions, deployed on an ad hoc basis. In addition to the general lack of interoperability between solutions, this also results in a lack of transparency of the ways in which smart waste solutions are offered. As a consequence, there is a lack of consistency in smart waste management solution provision, and a confused understanding as to what this application involves. This work therefore seeks to understand the extent to which perceptions of smart waste management vary.

\section{Research Methodology}

It is stated in [22] that, "Cities are, in the end, about the people and not the systems within them". The system must meet the needs of citizens, and be designed in such a way that the negative aspects of a society are minimised, such as social exclusion or poverty; if systems are designed ineffectively, they will exacerbate problems within a city. In relation to waste management, this could lead to overflowing bins which are unemptied or collections being organised for bins which do not justify emptying. Both problems result in an ineffective use of waste management resources, from the perspectives of the bins and waste collectors, respectively. It is therefore important to understand the perspectives of citizens in general and, specific to the objectives of this paper, those who will be exposed to the smart waste collection strategy. Citizens can have diverse understandings of the term 'smart waste management' because they may not have been communicated with in a consistent way or because they are not equally educated. We do not wish to suggest that this is a problem - instead, the objective of this work is to understand the ways in which smart city services are viewed and perceived so that solutions can be appropriately targeted to respond to these perspectives.

An online survey was disseminated using Google Forms to twenty-five homeowners within the Tourism Ireland office in Coleraine, Northern Ireland [23] from the Coleraine, Ballymoney, Portrush and Portstewart areas of Northern Ireland, United Kingdom in 2019. Seventeen people responded to our survey request. The objective was to gather the typical citizen perspective of smart cities, their views on the meaning of 'smart waste management', and any features which they would like to experience with regard to their waste collection process and/or schedule in a future smart city. The people who responded to the survey were within the 35-50 years old age range, with $60 \%$ male and $40 \%$ female, and living in family homes i.e., with a partner and children. Qualitative analysis was used to process the survey results, which are presented in Section 4.

\section{Survey on Smart Waste Management}

The survey responses that are presented across Tables 1 to 5 capture individual answers received from each respondent. The qualitative analysis of the survey responses presented in the tables discuss the issues which are agreed by the majority of participants.

Table 1 captures citizen perspective on the term 'smart city' by answering, "What does the term 'smart city' mean for you?" Some respondents believe that a smart city is one focused on energy, efficiency and sustainability. According to these respondents, a smart city is:

$$
\begin{aligned}
& \text { - "A city with good recycling plans" (1.9) } \\
& \text { - "Eco-friendly" (1.10) } \\
& \text { - "Efficient in terms of energy" (1.14) }
\end{aligned}
$$

This is not a surprising belief, with recognition in the literature of an overlap in the terms 'smart city' and 'sustainable city', as in [24] and [25]. A perspective which was originally more focused on sustainability has evolved to become smart city goals of a social and economic nature: "In recent years, there has been a shift in cities striving for smart city targets instead of sustainability goals" [24]. While sustainability may be part of what a smart city is about, other goals also exist, such as convenience, cost efficiency, and social inclusion. 
Table 1. What does the term 'smart city' mean for you?

\begin{tabular}{|c|c|}
\hline $\begin{array}{l}\text { Survey } \\
\text { Respondent } \\
\text { ID }\end{array}$ & Survey Respondent Comment \\
\hline 1.1 & "A lot of functions are carried out online" \\
\hline 1.2 & $\begin{array}{l}\text { "A city which is up to date on } \\
\text { technological advancements" }\end{array}$ \\
\hline 1.3 & $\begin{array}{l}\text { "A city that uses technology to better } \\
\text { understand its needs" }\end{array}$ \\
\hline 1.4 & "A city that anticipates your future needs" \\
\hline 1.5 & $\begin{array}{l}\text { "Physical infrastructure like transport, } \\
\text { water, waste management, lighting, etc., } \\
\text { all connected to the internet and able to } \\
\text { provide useful, real time information" }\end{array}$ \\
\hline 1.6 & $\begin{array}{l}\text { "I think that a Smart City is an area that } \\
\text { uses data to manage resources" }\end{array}$ \\
\hline 1.7 & $\begin{array}{l}\text { "City which uses technology to create a } \\
\text { sustainable future for itself" }\end{array}$ \\
\hline 1.8 & $\begin{array}{l}\text { "Using current data and technology to } \\
\text { efficiently manage the running of a } \\
\text { city/urban area - e.g., management of } \\
\text { traffic, schools, hospitals, waste } \\
\text { management, etc." }\end{array}$ \\
\hline 1.9 & "City with good recycling plans" \\
\hline 1.10 & "Eco-friendly" \\
\hline 1.11 & $\begin{array}{l}\text { "Wi-Fi enabled, sustainable and services } \\
\text { all available online" }\end{array}$ \\
\hline 1.12 & $\begin{array}{l}\text { "Not a term l'm familiar with before this } \\
\text { survey" }\end{array}$ \\
\hline 1.13 & "Technology is used to manage the city" \\
\hline 1.14 & "Efficient in terms of energy" \\
\hline 1.15 & $\begin{array}{l}\text { "Joined up thinking to maximise IT and } \\
\text { process across various aspects of public } \\
\text { services" }\end{array}$ \\
\hline 1.16 & $\begin{array}{l}\text { "A smart city is an urban area that uses } \\
\text { different types of electronic data } \\
\text { collection sensors to supply information } \\
\text { used to manage assets and resources } \\
\text { efficiently" }\end{array}$ \\
\hline 1.17 & $\begin{array}{l}\text { "Internet connected to the world and } \\
\text { using data to plan and manage" }\end{array}$ \\
\hline
\end{tabular}

This is not, however, the only perspective of a smart city, as indicated by other respondents: A number of respondent descriptions identify one aspect of smart city operation. Merging the responses from multiple respondents therefore allows a more complete definition to be reached. By merging respondent responses, a smart city is:

A city which is up to date on technological advancements (1.2), which can be used to better understand its needs (1.3) and to anticipate future needs (1.4) to manage the city (1.13). The physical infrastructure, like transport, water, waste management and lighting are connected to the Internet and provide useful real-time information (1.5) which can be used to efficiently manage the running of a city/urban area (1.8).
Table 2. What Does 'Smart Waste Management' Mean?

\begin{tabular}{|c|c|}
\hline $\begin{array}{l}\text { Survey } \\
\text { Respondent } \\
\text { ID }\end{array}$ & Survey Respondent Comment \\
\hline 2.1 & $\begin{array}{l}\text { "Waste is sorted, weighed and recorded } \\
\text { automatically" }\end{array}$ \\
\hline 2.2 & $\begin{array}{l}\text { "Waste which is disposed of efficiently with } \\
\text { the use of up to date software" }\end{array}$ \\
\hline 2.3 & $\begin{array}{l}\text { "Waste management that uses technology } \\
\text { to increase efficiency and help with } \\
\text { recycling" }\end{array}$ \\
\hline 2.4 & $\begin{array}{l}\text { "That it's easier to recycle and there's no } \\
\text { unnecessary packaging" }\end{array}$ \\
\hline 2.5 & $\begin{array}{l}\text { "Unsure but maybe knowing how much } \\
\text { waste is in your bins at any time, and the } \\
\text { bin being able to schedule a pickup } \\
\text { automatically when it gets to a certain } \\
\text { level" }\end{array}$ \\
\hline 2.6 & $\begin{array}{l}\text { "I think it means using data to smartly } \\
\text { control the amount of waste within a } \\
\text { specific area" }\end{array}$ \\
\hline 2.7 & $\begin{array}{l}\text { "Best systems and processes to reduce } \\
\text { overall waste and increase recycling \%" }\end{array}$ \\
\hline 2.8 & $\begin{array}{l}\text { "Using data to ensure that proper waste } \\
\text { management facilities are in place for } \\
\text { respective city, urban and regional areas \& } \\
\text { that these waste management facilities are } \\
\text { as efficient as possible" }\end{array}$ \\
\hline 2.9 & "Well planned recycling system" \\
\hline 2.10 & $\begin{array}{l}\text { "Recycling rather than 'conventional' waste } \\
\text { disposal" }\end{array}$ \\
\hline 2.11 & "Recyclable waste management" \\
\hline 2.12 & $\begin{array}{l}\text { "Good recycling and waste minimisation in } \\
\text { the first instance" }\end{array}$ \\
\hline 2.13 & $\begin{array}{l}\text { "Managing waste using technology to save } \\
\text { human time and energy" }\end{array}$ \\
\hline 2.14 & "Managing waste smartly!" \\
\hline 2.15 & $\begin{array}{l}\text { "I haven't heard this before, but I presume } \\
\text { it is about minimisation and collection at } \\
\text { appropriate times" }\end{array}$ \\
\hline 2.16 & $\begin{array}{l}\text { "Managing the level of waste within city } \\
\text { bins through monitoring with sensors" }\end{array}$ \\
\hline 2.17 & $\begin{array}{l}\text { "Reducing one way use of resources and } \\
\text { having an Internet enabled solution" }\end{array}$ \\
\hline
\end{tabular}

In contrast, it is interesting to observe that fewer survey respondents are familiar with the concept of smart waste management within a smart city:

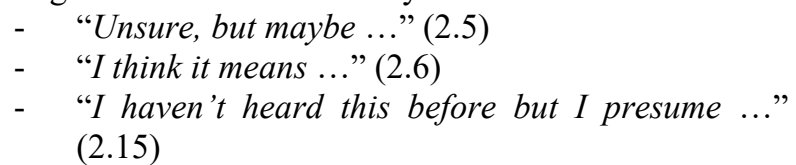
Responses to the question, "What does 'smart waste management' mean" are presented in Table 2. The responses provide evidence that society, in general, is unclear on the meaning of the term 'smart waste management'. A number of responses are vague and do not clearly describe smart waste management. For 
example, respondents indicated that smart waste management is:

- "Waste which is disposed of efficiently" (2.2)

- "Waste management that uses technology to increase efficiency" (2.3)

- "Managing waste using technology" (2.13)

- "Reducing one way use of resources" (2.17)

This provides evidence that citizens are not certain about what 'efficiency' means with regard to waste management, or how waste is managed using technology. Several respondents consider smart waste management from the perspective of effort to reduce the waste amount:

- "Best systems and processes to reduce overall waste ..." (2.7)

- "I presume it is about minimisation" (2.15)

This is a limited perspective of the concept of smart waste management. Furthermore, this angle overlaps with the notion of a smart city being synonymous with sustainability and, essentially, recycling. A selection of the descriptions of smart waste management consider it more explicitly from the perspective of recycling. For example:

- "That it's easier to recycle" (2.4)

- "Well planned recycling system" (2.9)

- "Recycling rather than 'conventional' waste disposal" (2.10)

- " "Recyclable waste management" (2.11)

Again, this is a limited perspective of what smart waste management involves.

Some respondents did, however, recognise the 'correct' meaning of this concept. We consider 'correctness' from the perspective of the state-of-the-art waste management solutions presented in Section 2. Descriptions which we consider to be more representative include:

- "Knowing how much waste is in your bins at any time, and the bin being able to schedule a pickup automatically when it gets to a certain level" (2.5)

- "Managing the level of waste within city bins through monitoring and sensors" (2.16)

It is on the basis of these definitions that the research is presented in this paper.

\section{Smart Waste Management Challenges}

From the survey, some interesting points are raised: In the case of the smart waste management scheme, which typically involves a sensor integrated in a bin and the bin level autonomously being communicated to the waste collection depot for collection once it passes a threshold level, this introduces new challenges. For example, the homeowner needs to be aware that their bin collection has been autonomously scheduled so that they may leave the bin outside the property for pickup. If this is not done, the waste collectors would need permission to enter the property to collect the bin. Without permission, the bin will be unable to be collected. In both instances, the intended objective of improved efficiency of the smart waste management scheme will have failed.
A further notable finding is that homeowners acknowledge improvements are necessary with regard to their current bin collection schedule, and would ideally involve collections with greater frequency. Again, this does not indicate that the new scheme will operate with improved efficiency, as one goal is to optimize the need to collect bins on a set schedule. However, the fact that respondents made this comment confirms that there is scope for improvement of the current collection approach. Influencing the collection strategy in a manner convenient for citizens and more efficient overall is one approach to provision waste management in smart cities. Through the survey, we wished to identify any further ways in which waste management could be modified to respond to needs. Survey respondents were therefore asked: "Are you dissatisfied with any aspect of your bin collection schedule?"

The responses in Table 3 validate that citizens are generally unsatisfied with their waste collection service, as the majority have an opinion on how it could be improved. This also indicates that waste collection is relatively important in their lives, given the fact that so many have opinions on it. These citizens are not exposed to smart waste collection services; their feedback could therefore be used to help to understand the way in which smart city services could be put in place. There is a

Table 3. Are you Dissatisfied with any Aspect of your Bin Collection Schedule?

\begin{tabular}{|l|l|}
\hline $\begin{array}{l}\text { Survey } \\
\text { Respondent } \\
\text { ID }\end{array}$ & Survey Respondent Comment \\
\hline 3.1 & "No" (x 5) \\
\hline 3.2 & $\begin{array}{l}\text { "Recyclables could be broken further } \\
\text { down" }\end{array}$ \\
\hline 3.3 & $\begin{array}{l}\text { "Often too far apart, sometimes the bin is } \\
\text { over capacity, other times there is plenty of } \\
\text { room in it" }\end{array}$ \\
\hline 3.4 & $\begin{array}{l}\text { "It would be good if we had a bin for garden } \\
\text { waste" }\end{array}$ \\
\hline 3.5 & $\begin{array}{l}\text { "Yes, my bin is often not collected for } \\
\text { unknown reasons" }\end{array}$ \\
\hline 3.6 & $\begin{array}{l}\text { "Recycling/organic waste is only bi monthly } \\
\text { and this is inadequate especially if you are } \\
\text { grass cutting or have lots of cardboard to } \\
\text { recycle" }\end{array}$ \\
\hline 3.7 & $\begin{array}{l}\text { "not all bins need collected as often as they } \\
\text { are and some need collected more } \\
\text { regularly than they are collected" }\end{array}$ \\
\hline 3.8 & $\begin{array}{l}\text { "Generally it's a good service, but recycling } \\
\text { collections can be troublesome if you } \\
\text { accidentally try to include something that's } \\
\text { not on the approved list" }\end{array}$ \\
\hline 3.9 & $\begin{array}{l}\text { "Could do with being emptied more over } \\
\text { holiday periods" }\end{array}$ \\
\hline 3.10 & $\begin{array}{l}\text { "Remembering which bin on alternate } \\
\text { weeks is mildly frustrating in this techie } \\
\text { age" }\end{array}$ \\
\hline
\end{tabular}


feeling in the citizen responses that personal scheduling of the waste collection schedule would be a benefit, given that "sometimes the bin in overflowing, other times there is plenty of room in it" (3.3), and "not all bins need collected as often as they are and some need collected more regularly than they are collected" (3.7). Responses also indicate that citizens have dissatisfaction with the recycling collection service, in particular. For example, a feeling is that "recyclables could be broken down further" (3.2) and "recycling/organic waste is only bi monthly and this is inadequate" (3.6). There is also a feeling that technology could reasonably be expected to support the waste collection service, with an opinion that "Remembering which bin on alternate weeks is mildly frustrating in this techie age" (3.10).

Given opinions in [10] which acknowledge that smart city services are generally launched without the approval of citizens, we wished to capture how our survey respondents believed that their waste collection service could be improved, such that recommendations could be made to provide a service which responds to society's needs. Respondents were therefore asked: "How could bin collection services be improved?" Responses are presented in Table 4.

One of the responses to this question makes a particularly interesting point, which may become a larger problem once or if smart waste technology is deployed. This respondent recommends one modification to their bin collection service as, once the bin level sensor technology has identified that the fill level is above a threshold and has scheduled a collection, "Could they ... have permission to enter and remove so I don't always have to remember to put bin out and which color is being collected on which date" (4.11). In the case that a bin has been scheduled for collection autonomously, the homeowner may not be aware of this fact and they may not be at home in order to place the bin for collection the bin may therefore not be positioned at the front of the house for its collection. If the bin collector has permission to enter the property to empty the bin, this will increase the time associated with a collection and therefore its efficiency. Similarly, if the collector does not have permission to enter the property, the efficiency of the pickup will be reduced by not collecting at least one of the bins on the planned route.

Recycling is identified as a priority area:

- "recyclables could be better sorted" (4.1)

- "more information on recycling and bottle banks" (4.2)

- "Incentives could be introduced to encourage better recycling" (4.8)

Several responses indicate concern with the frequency of collection, with respondents desiring:

- "Greater frequency of collections" (4.1)

- "More frequency" (4.2)

- "Perhaps a more frequent collection for black bins as these appear to be the bins that fill up the quickest" (4.6)

\section{Table 4. How Could Bin Collection Services be Improved?}

\begin{tabular}{|c|c|}
\hline $\begin{array}{l}\text { Survey } \\
\text { Respondent } \\
\text { ID }\end{array}$ & Survey Respondent Comment \\
\hline 4.1 & $\begin{array}{l}\text { "Greater frequency of collections, } \\
\text { recyclables could be better sorted" }\end{array}$ \\
\hline 4.2 & $\begin{array}{l}\text { "More frequency and more information on } \\
\text { recycling and bottle banks" }\end{array}$ \\
\hline 4.3 & "I am not sure" \\
\hline 4.4 & "Don't know" \\
\hline 4.5 & $\begin{array}{l}\text { "Bins are collected when they are full, not } \\
\text { when scheduled" }\end{array}$ \\
\hline 4.6 & $\begin{array}{l}\text { "Perhaps a more frequent collection for } \\
\text { black bins as these appear to be the bins } \\
\text { that fill up the quickest" }\end{array}$ \\
\hline 4.7 & $\begin{array}{l}\text { "Rename bins (black, green, etc.) in a way } \\
\text { which relates to their impact on } \\
\text { environment" }\end{array}$ \\
\hline 4.8 & $\begin{array}{l}\text { "It seems ludicrous that the same charges } \\
\text { are applied to six person and one person } \\
\text { households as the latter would generate } \\
\text { much less waste. Incentives could be } \\
\text { introduced to encourage better recycling. } \\
\text { Also there should be fines imposed for } \\
\text { those who stuff their bins to capacity and } \\
\text { end up littering the general area as bins } \\
\text { are too full." }\end{array}$ \\
\hline 4.9 & "No" \\
\hline 4.10 & $\begin{array}{l}\text { "A reason as to why a bin is not collected } \\
\text { would be useful" }\end{array}$ \\
\hline 4.11 & $\begin{array}{l}\text { "Could they know (by smart technology) } \\
\text { when to collect and have permission to } \\
\text { enter and remove so I don't always have to } \\
\text { remember to put bin out and which color is } \\
\text { being collected on which date." }\end{array}$ \\
\hline 4.12 & $\begin{array}{l}\text { "Collect some bins more frequent than } \\
\text { others" }\end{array}$ \\
\hline 4.13 & $\begin{array}{l}\text { "Collect slightly later in the day - after rush } \\
\text { hour" }\end{array}$ \\
\hline 4.14 & $\begin{array}{l}\text { "Would be better if the bin men didn't throw } \\
\text { the bins around and break them into bits" }\end{array}$ \\
\hline 4.15 & "Identified days for electrical or bulky items" \\
\hline
\end{tabular}

The fact that respondents desire their bins to be collected with greater frequency indicates that there are times when bins are full yet homeowners have to wait for the next scheduled collection. If bins are collected as soon as possible after they are full when a smart waste management mechanism has been deployed, there will potentially be a collection strategy which is executed with greater frequency than at present; this does not fulfil a smart waste management goal of improved efficiency. This is an aspect which needs to be managed separately. Furthermore, in the collection of bins which are full, there may be less efficiency than if every bin in a street were collected, regardless of its fill level. 
This inefficiency is acknowledged by respondents in their response to the question, "How do you think that a bin collection schedule which you are in control of would differ from the one which the local council has defined?" Responses are presented in Table 5.

In terms of efficiency, respondents consider that a citizen-centric waste management mechanism:

"Would be more frequent but cost more" (5.1) and even that it might lead to:

"Inefficiency and chaos" (5.3)

This response is interesting, in recognition of the fact that respondents realise the difficulties associated with the approaches they potentially desire from smart waste management solutions. Other respondents do not have any expectations:

$$
\begin{aligned}
& \text { - "Don't know" (5.4) } \\
& \text { - "Not sure" (5.6) } \\
& \text { - "Would be similar" (5.11) }
\end{aligned}
$$

Another common opinion is the need to collect more types of waste, including "bulky items and garden waste" (5.12).

However, it is also interesting, that beyond general inefficiency concerns, respondents do not identify any other challenges associated with smart waste management, such as a bin collection being scheduled when the homeowner is not expecting it, and the

Table 5. How do you Think that a Bin Collection Schedule which you are in Control of Would Differ from one which the Local Council has Defined?

\begin{tabular}{|l|l|}
\hline $\begin{array}{l}\text { Survey } \\
\text { Respondent } \\
\text { ID }\end{array}$ & Survey Respondent Comment \\
\hline 5.1 & "Would be more frequent but cost more" \\
\hline 5.2 & "More frequency" \\
\hline 5.3 & $\begin{array}{l}\text { "Inefficiency and chaos. One run of all the } \\
\text { houses once a week is better than bin } \\
\text { trucks coming and going every single day" }\end{array}$ \\
\hline 5.4 & "Don't know" \\
\hline 5.5 & $\begin{array}{l}\text { "It would be much better and more } \\
\text { environmentally friendly" }\end{array}$ \\
\hline 5.6 & "Not sure" \\
\hline 5.7 & "More flexible and more things collected" \\
\hline 5.8 & $\begin{array}{l}\text { "You would decide when the bin needs } \\
\text { collect and therefore not have to plan to } \\
\text { a predefined schedule" }\end{array}$ \\
\hline 5.9 & "More communal bins" \\
\hline 5.10 & $\begin{array}{l}\text { "I think sometimes I wouldn't need rubbish } \\
\text { amount of times l'd need them to collect" } \\
\text { "Would be similar" }\end{array}$ \\
\hline 5.11 & $\begin{array}{l}\text { "More pick ups for bulky items and garden } \\
\text { waste" }\end{array}$ \\
\hline 5.12 & $\begin{array}{l}\text { "There would be better recycling facilities } \\
\text { and fines for contamination of recycling } \\
\text { bins. Costs would be determined based on } \\
\text { household waste production rather than a } \\
\text { general "one size fits all" fee." }\end{array}$ \\
\hline 5.13 &
\end{tabular}

subsequent impacts that this can have. This provides further evidence that respondents do not fully understand the term 'smart waste management'.

In this paper, it is our aim to gain an appreciation of citizen perspectives on the concept of smart waste management, as one area of focus in a smart city. Our survey results indicate some degree of consistency in that citizens are largely unclear on the smart city concept, and what smart waste management involves. To summarise our findings: There is overlap in understanding in relation to what a smart city is and general sustainability concepts, with respondents believing that a smart city is one in which sustainability is prioritised. This misconception follows into understanding of the term 'smart waste management', with some considering this aspect of smart cities to be primarily involved with recycling. In general, homeowners acknowledge that improvements to their current bin collection schedule are necessary: Some are dissatisfied with the recycling collection service, and some believe that technology could support the process in a more effective way. Interestingly, citizens recognise the challenges of provisioning an improved smart waste management service, and are sympathetic to the fact that service improvements have not been made to date.

To relate our findings to studies within the field: The literature examines the extent to which smart cities are citizen-focused, as in [26]; this is an obvious question to ask, given that smart cities are purported to be rolled out to improve the lives of citizens [27]. It is reported that smart cities in general are not citizen-focused; our findings concur with this, given the general dissatisfaction with current waste collection services. Smartivists, a relatively recent term, describes citizens who take active steps to contribute to the smart city concept voluntarily [28]. While this is difficult to achieve in the case of waste management, given that it is the government who controls this service, we believe that our survey respondents have gone some way in demonstrating their ability to operate in this role, through their suggestions as to how waste collection processes may be made more satisfactory. It is also widely recognised that, "Citizens must be involved in creating smarter digital cities" [29]. We believe that the results of our survey contribute a range of perspectives on the scope for improving the transparency of smart city and smart waste management concepts, in addition to opinions on how waste management can be improved.

The survey findings can be applied in the field. They demonstrate that there is opportunity to improve transparency of the terms 'smart city' and 'smart waste management' to bring the general citizen perspective in line with the reality. The survey responses also give specific ideas on ways in which waste collection processes could be adapted to fulfil citizen desires across smart cities. This takes into account, for example, facilitating greater sorting of recyclables, in addition to having greater frequency of collections. Application of the findings in another or a more general field can also be achieved through identification that citizens generally want more flexibly in their service, a fact which could be 
applied to most, if not all, IoT domains. The smart city, enabled by IoT technology, is one which makes the lives of citizens easier and more comfortable. The survey responses provide recommendations as to possible ways in which this could be achieved in relation to waste management, considering, for example, that some citizens would appreciate a greater service frequency and greater responsiveness from waste collectors. One respondent in particular noted a desire to move away from a "one size fits all" approach to waste management. The degree of personalisation which is possible as a result of IoT technology allows this to be achieved across the supported domains. Of course, there are associated challenges of operating in this way including, for example, increased costs. Further investigation which considers how this might be accommodated within our programme of work is therefore presented in Section 6 .

\section{Implications of our Findings on the Service Level Agreement (SLA) Provisioning Process}

Without a common and realistic understanding of what smart cities and smart services involve, there is potential that customers will not participate as actively as they might otherwise, and they may take on a service plan which is inappropriate for their needs. Our findings reveal that citizens want access to services which they are in control of. This may lead to a greater range of waste items being collected, being collected on a flexible schedule, and fines being charged for customers who do not comply with the terms of their SLA. Such a strategy leads to a need for sensor readings being passed from the bins to a centralised data repository, at a rate which might vary depending on the frequency of change in the fill level, or some personal characteristic e.g., age or location, which can be used as a proxy for a citizen's waste disposal behaviour.

Service Level Agreements are typically defined today using a basic set of attributes, which can include the number of messages a user intends to send or the amount of storage space which they want to use. Users who are participating in smart city services, however, may not have that technical expertise to know how their service should be personalised - they just know that they want certain outcomes from a particular service, such as ondemand collection. It then becomes the responsibility of the provider to understand this, to ensure that the user achieves a Quality of Experience (QoE) that they are satisfied with. This drives a need for SLAs which are flexible, with the option of adapting the terms of their agreement after a customer has agreed to it, for example, by scaling the volume of operations which a customer is involved in. This goes beyond the capabilities which exist in the SLA provisioning process today.

It might therefore become the case that an ontology is created to support the smart waste management process, which can be populated and subsequently probed by a service provider to understand the suitability of the service being provided in responding to customer needs. Similarly, the data collected via the ontology can be probed by waste collectors to appreciate the customer needs for their waste collection, in addition to their satisfaction with the services provided. Operating such an approach leads to opportunities for new business models to bill the parties engaged in this process - where we have a service provider, city council, homeowner, and potentially third parties involved in this process, this becomes a significantly more complex billing process than we see today. Nonetheless, the smart city is in itself a business model, and it is for the purpose of revenue generation that partners engage. There are subsequently significant implications arising from making a decision to operate the smart waste management domain according to the opinions and perspectives captured in this paper through our homeowner survey. We are considering the range of aspects discussed in this section in our further work.

\section{Conclusions}

While waste management can be smart, it is not always obvious in the approaches described in the literature if they are truly efficient. The state-of-the-art in waste management does not go far beyond a route planning schedule dictated by the fill level of bins, which is identified using sensors deployed on the bin and is communicated back to the waste collection depot. This is intended to improve efficiency of the process by initiating the waste collection process only when bins are full and avoiding needlessly collecting bins which have been filled below this level. This does not, however, take into account the number of bins which have been filled above the threshold when scheduling collections, therefore ensuring that once a collection has been scheduled, that there is also a threshold number of bins being emptied to maximise the efficiency of the collection. There is therefore a challenge introduced in smart waste management by the variable rate at which bins are filled. If the bin collection does not take place within a relatively short time period after the fill being identified and the route has been dynamically determined, there is potential that the route will no longer be the most efficient.

Respondents to this survey reveal that, while waste management is an important part of their lives, they do not have a clear understanding of the concept of smart waste management, and that they do not fully appreciate its consequences.

\section{References}

[1] AlHogail, A. Improving IoT Technology Adoption through Improving Customer Trust. Technologies 2018, 6(3). 64, Jul. 2018, pp. 1-17. 
[2] Ceballos, G. R., Larios, V. M. A Model to Promote Citizen Driven Government in a Smart City. Proc. of IEEE International Smart Cities Conference, Sep. 2016, pp. 1-6.

[3] Ceballos, G. R. and Larios, V. M. A Model to Promote Citizen Driven Government in a Smart City: Use Case at GDL Smart City. Proc. of IEEE International Smart Cities Conference, Sep. 2016, pp. 1-6.

[4] Eden Strategy Institute. Top 50 Smart City Governments. 2018. Available: https://www.smartcitygovt.com/ (last accessed: 25 Jan. 2020).

[5] ISO. Smart Cities. ISO Focus+, Vol. 4, No. 1, Jan. 2013; ISSN 2226-1095.

[6] Liotine, M., Ramaprasad, A. and Syn, T. Managing a Smart City's Resilience to Ebola: An Ontological Framework. Proc. of 49th Hawaii Int. Conf. on System Sciences, Jan. 2016, pp. 2935- 2943.

[7] Cohen, B. The Smart City Wheel. May 2013 [Online]; Available: https://www.smartcircle.org/smartcity/blog/boyd-cohen-the-smart-city-wheel/ (last accessed: 25 Jan. 2020).

[8] Cisco. What is a Smart City. [Online]; Available: https://www.cisco.com/c/en/us/solutions/industries/smartconnected-communities/what-is-a-smart-city.html (last accessed: 25 Jan. 2020).

[9] ITU-T. SG20: Internet of Things (IoT) and Smart Cities and Communities. [Online]. Available: https://www.itu.int/en/ITU-T/studygroups/20172020/20/Pages/default.aspx (last accessed: 25 Jan. 2020).

[10] ITU-T. Smart Sustainable Cities at a Glance. [Online]. Available: https://www.itu.int/en/ITU-T/ssc/Pages/infossc.aspx (last accessed: 25 Jan. 2020).

[11] ETSI. Smart Cities. [Online]. Available: https://www.etsi.org/technologies/smart-cities (last accessed: 25 Jan. 2020).

[12] Joinip. Smart Cities / Technologies and Services for Smart and Efficient Energy Use. [Online]. Available: joinup.ec.europa.eu/collection/rolling-plan-ictstandardisation/smart-cities-technologies-and-servicessmart-and-efficient-energy-use (last accessed: 25 Jan. 2020).

[13] Aazam, M., St-Hilaire, M., Lung, C-H. and Lambadaris, I. Cloud-based Smart Waste Management for Smart Cities. Proc. of 21st IEEE International Workshop on Computer Aided Modelling and Design of Communication Links and Networks, Oct. 2016, pp. 188-193.

[14] IBM. IBM Intelligent Waste Management Platform. [Online] IBM White Paper, Dec. 2015. Available: https://www.govloop.com/wpcontent/uploads/2015/12/intelligent_waste_management_p aper_- final_12152015.pdf (last accessed: 25 Jan. 2020).

[15] Government Europa. Solar-powered, IoT-connected Bins Installed in UK Borough. Jul. 2018. Available: https://www.governmenteuropa.eu/solar-powered-iotconnected-bins/89545/ (last accessed: 25 Jan. 2020).

[16] Marchiori, M. The Smart Cheap City: Efficient Waste Management on a Budget. Proc. of 19th Int. Conf. on High Performance Computing and Communications, 15th Int. Conf. on Smart City, and 3rd Int. Conf. on Data Science and Systems, 2017, pp. 192-199.

[17] Mahmood, I. and Zubairi, J. A. Efficient Waste Transportation and Recycling. IEEE Electrification Magazine, Sep. 2019, pp. 33-43.

[18] Catarinucci, L., Colella, R., Consalvo, S. I., Patrono, L., Salvatore, A. and Sergi, I. IoT-oriented Waste Management System based on new RFID-Sensing Devices and Cloud Technologies. Proc. of 4th International
Conference on Smart and Sustainable Technologies, Jun. 2019, pp. 1-5.

[19] Lu, J-W., Chang, N-B., Liao, L., and Liao, M-Y. Smart and Green Urban Solid Waste Collection Systems: Advances, Challenges, and Perspectives. IEEE Systems Journal, Vol. 11, No. 4, Dec. 2017, pp. 2804-2817.

[20] Enevo Homepage. Available: https://enevo.com/ (last accessed: 25 Jan. 2020).

[21] Cisco. Cisco Kinetic for Cities Waste Management. [Online]. Available: https://www.cisco.com/c/en/us/solutions/industries/smartconnected-communities/kinetic-for-cities-wastemanagement.html (last accessed: 25 Jan. 2020).

[22] Burdett, R. The Heart of the City. Financial Times, Apr. 2010. Available: https://www.ft.com/content/102bd24a38d4-11df-9998-00144feabdc0 (last accessed: 25 Jan. 2020).

[23] Tourism Ireland Homepage. Available: https://www.tourismireland.com/.

[24] H. Ahvenniemi, A. Huovila, I. Pinto-Seppa and M. Airaksinen. What are the Differences between Sustainable and Smart Cities? Elsevier Cities, Vol. 60, Part A, Feb. 2017, pp. 234-245.

[25] Greco, I. and Bencardino, M. The Paradigm of the Modern City: SMART and SENSEable Cities for Smart, Inclusive and Sustainable Growth. Proc. of the International Conference on Computational Science and its Applications, Jun. 2014, pp. 1-19.

[26] Sánchez-Teba, E. M. and Bermúdez-González, G. J. Are Smart-City Projects Citizen-Centered? MDPI Social Sciences, 8, 309, Nov. 2019, pp. 1-9.

[27] Wendorf, M. Smart Cities Initiatives around the World are Improving Citizens' Lives. Interesting Engineering, Available: https://interestingengineering.com/smart-citiesinitiatives-around-the-world-are-improving-citizens-lives (last accessed: 25 Jan. 2020).

[28] Bee Smart City. Rise of Smartivist. Available: https://hub.beesmart.city/smartivists/rise-of-the-smartivistthe-importance-of-smart-citizens-in-smart-cities (last accessed: 25 Jan. 2020.)

[29] Walker, A. Citizens Must be Involved in Creating Smarter Digital Cities. Infrastructure Intelligence, Oct. 2019. Available: $\mathrm{http}: / / \mathrm{www}$. infrastructureintelligence.com/article/oct-2019/citizens-must-beinvolved-creating-smarter-digital-cities (last accessed: 25 Jan. 2020). 